DOI https://doi.org/10.30525/978-9934-26-004-9-4

\title{
ЖИТОМИРСЬКИЙ ПЕРІОД ТВОРЧОСТІ \\ В. КОСЕНКА: СПЕЦИФІЧНІ РИСИ, ЗНАЧЕННЯ, КУЛЬТУРНО-ІДЕЙНИЙ КОНТЕКСТ
}

\author{
Даценко В. П. \\ здобувачка \\ Національної академії керівних кадрів культури і мистецтвв \\ м. Київ, Україна, \\ викладач ииклової комісії спеціального фортепіано \\ Житомирського фахового музичного коледжу \\ імені В. С. Косенка Житомирської обласної ради \\ м. Житомир, Украӥна
}

У житомирський період своєї творчості (1919-1928 рр.) композитор В. Косенко розгорнув велику і виконавську й творчу діяльність. Він бере активну участь в музичному житті міста, виступає у відкритих концертах як соліст і акомпаніаторі.

В зазначений час творчості ряд змін у музиці В. Косенка відбувалися під впливом зближення композитора 3 масовим слухачем, зі студентською, просвітницькою, робітничою аудиторією. Він все гостріше відчував однобічне спрямування своєї музи, недостатньо дійовий зв'язок своєї творчості з життям тодішнього соціуму УРСР.

Видатний композитор нерозривно пов'язав свою творчу долю 3 дійсністю своєї країни, відразу ж після розпаду Російської імперії активно включився у музично-громадське життя. Чудовий піаніст, він пропагував вітчизняну та зарубіжну класичну музику. Численні концертні виступи в робітничих аудиторіях, військових частинах, перед інтелігенцією стали життєвою необхідністю митця. Географія таких подорожей постійно розширювалась й охопила такі промислові центри, як Донбас, Харків, Київ. Це був безпосередній відгук на вимоги культурних перетворень в УРСР, зокрема на заклик залучати широкі верстви населення до кращих надбань світової культури. Поступової еволюції зазнали творчість В. Косенка, його образне мислення: від суб'єктивного світогляду, нестійких, екзальтованих настроїв у перших невеликих фортепіанних п'єсах, романсах - до повнокровних, життєствердних образів у патріотичних піснях, симфонічних композиціях на актуальні громадянські теми. 
На гастролі до Житомира часто приїздили співаки, скрипалі. Багато із них зупинялись на квартирі В. Косенка. В особі молодого піаніста вони знаходили чудового концертмейстера. Напружені, а потім успішні виступи приносили творчу радість. У Косенка був неабиякий досвід ансамблевої гри. Ще навчаючись, він заради матеріального забезпечення багато працював 3 артистами у театрі, акомпанував, розучував арії, романси. Ця робота не пройшла безслідно. Здобуті навики дали плідні результати.

За цей час В. Косенко створив велику кількість солоспівів на тексти О. Апухтіна, К. Бальмонта, О. Блока, М. Огарьова, Ф. Тютчева. У них композитор темпераментно й щиро розкрив тему кохання. У романсах «Вони стояли мовчки», «Я ждав тебе», «Ні відгуку, ні слова», «І знов в моїй душі» та ін. настрої туги, самотності чергуються 3 полум'яною й романтичною пристрастю. Це загалом коло образів романсової лірики П. Чайковського і С. Рахманінова, якій твори Косенка не поступаються по глибині виявлення почуттів, мелодійному багатству і досконалості вокальної та фортепіанної партій [6, с. 4].

В інструментальній музиці композитора того періоду можна зустріти приблизно ті самі образи та емоції. «12 романтичних етюдів», «Ноктюрнфантазія», «Дві поеми-легенди», «Трагічна поема» для фортепіано тощо, хоч змістовні й емоціональні, - розкривають нам світ суто інтимних настроїв і почуттів: спокійно-меланхолійна зосередженість чергується тут із схвильованим, навіть бурхливим драматично-трагедійним пориванням.

В роки зародження й становлення української музики радянського періоду В. Косенко не ставив перед собою кардинальних завдань щодо формування національної музичної мови, пошуків нових засобів виразності. Навпаки, він відстоював класичний стиль, активно впроваджував його форми й методи. Композитор постійно прагнув підносити національне мистецтво до високого професіоналізму, до вершин світової класики.

3 ім'ям В. Косенка пов'язані визначні досягнення української фортепіанної музики. Саме у фортепіанній творчості, яка займає центральне місце в доробку композитора, найбільші його здобутки. Він багато часу приділяв вдосконаленню виконавської майстерності, готуючи себе до концертної діяльності, якою, до речі, й займався постійно, особливо у 1920-і роки, популяризуючи твори різних авторів.

Фортепіанні твори В. Косенка насичені багатьма різноманітними піаністичними прийомами. В їх стилі, насамперед, привертають увагу такі якості, як м'якість тону, пластика музичної тканини, віртуозність, а 
також співуча кантилена. Цей стиль позначений рисами піанізму видатних композиторів-класиків. Зокрема, відчутний вплив Ф. Ліста, Р. Шумана, Е. Гріга, П. Чайковського i особливо Ф. Шопена, С. Рахманінова, О. Скрябіна.

Загалом увагу митця привертали різні сфери людського життя i діяльності: політико-громадянський пафос, романтика праці, духовний світ сучасника. В яких би жанрах не працював композитор, всюди відчуваються високий професіоналізм, майстерність, широка ерудиція. Його творче обдаровання зросло на вітчизняній і світовій класиці, естетичний світогляд співзвучний романтичним віянням. Композитор взяв за основу своєї творчості принципи і властивості класичного стилю. Мелодія виступає основним виражальним засобом, головним носієм музичної думки.

Симфонічна палітра В.Косенка характеризується насиченістю музично-тематичного матеріалу - багатотемністю, з одного боку, і не досить широкою розробкою основних тем, - 3 іншого. Композитор тяжів до так званого психологічного симфонізму, він дав яскраві зарисовки глибоких емоційних переживань через контрастні образи й динамічні співставлений.

Отже, саме у Житомирі протягом 1918-1929 рр. визрів блискучий талант В. Косенка як виконавця-піаніста i композитора-лірика. У складний період зародження й становлення української радянської музичної культури 20-х рр. В. Косенко у ході житомирського періоду своєї творчості створив високохудожні зразки камерної вокальної та інструментальної музики, ряд пісень, хорів і солоспівів та кілька симфонічних творів, що свідчили про високу професіональну майстерність композитора, демократичне спрямування його музики $\mathrm{i}$ дістали тоді широке громадське визнання.

Життя В.Косенка було недовгим, але змістовним, напруженим i водночас овіяним романтикою незвіданих шляхів. У процесі вивчення й дослідження життєвого шляху композитора через майже 100 років лише рельєфніше вимальовується роль художника-громадянина, патріота.

Спадщина Косенка житомирського періоду - це симфонічні, фортепіанні твори, інструментальні концерти, п’єси для інструментальних ансамблів, романси, обробки народних пісень. Загальний характер його музики позначений ліричною м'якістю, камерністю. Манера висловлювання - спокійна, стримала, а хід думок - природний, логічно послідовний. Водночас витонченій, мелодично наспівній мові притаманна внутрішня експресія. Багатство почуттів, романтична піднесеність, стрункість класичних форм - це якості, що становлять 
тривку життєву основу музики композитора у житомирський період його творчості і в подальшому.

\title{
Література:
}

1. В.С. Косенко у спогадах сучасників / упоряд.: А.В. Косенко. Київ : Музична Україна, 1967. 179 с.

2. В.С. Косенко. Спогади. Листи. Вид. 2-ге, доп. / упоряд. А.В. Косенко. Київ: Музична Україна, 1975. 295 с.

3. Гордійчук М. Українська радянська симфонічна музика. Київ, 1969. $304 \mathrm{c}$.

4. Довженко В. В. С. Косенко. Київ : Мистецтво, 1951. 125 с.

5. Довженко В. В.С. Косенко: нарис. Київ : Мистецтво, 1949. 140 с.

6. Довженко В. Героїчна увертюра В.Косенка. Київ : Мистецтво, 1963. $29 \mathrm{c}$.

DOI https://doi.org/10.30525/978-9934-26-004-9-5

\section{ПРАВОСЛАВИЕ - «ГЕНЕТИЧЕСКОЕ ЯДРО» РУССКОЙ КУЛЬТУРЫ}

\author{
Дубровская Г. Н. \\ кандидат искусствоведения, \\ дочент кафедры общего и специиализированного фортепиано \\ Одесской национальной музыкальной академии \\ имени А. В. Неждановой \\ 2. Одесса, Украина
}

1. Понятие «культура» многозначно, вмещающее духовнонравственные, религиозные и творческие аспекты: «образование умственное и нравственное, предполагающее и элементы творческие» (В. Даль) $[2,78]$; «творится не сознанием, не рассудком и не произволом, а целостным, длительным и вдохновенным напряжением всего человеческого существа, отыскивающего прекрасную форму для глубокого содержания; прежде всего, инстинктом... Вера есть духовный язык инстинкта» (И. Ильин) [4, с. 17].

2. Культура соотносима с культом: «возделывание», соотносимое с «земледелием», то есть истоками, почвой, корнями, произрастающими из культа (cultura от cultus)... Святыни - первичное творчество человека; культурные ценности - производные культа» (П. Флоренский) 